\section{Patenting of genes}

SIR - As a patent attorney and Human Genome Project enthusiast, I believe that the lead-in to your recent report ${ }^{1}$ on Craig Venter's patenting of uncharacterized cDNAs deserves some clarification. Patenting genes relating to genetic disorders such as cystic fibrosis (CF), Huntingon's disease (HD) and Duchenne muscular dystrophy (DMD) is not, as stated in your article, "business as usual". This is illustrated by a preliminary patent search, summarized in the table, directed towards these disorders.

This table indicates, first, that there are numerous, potentially conflicting, patent applications being filed in this area. This is frequently true in the case of biotechnology patents. Second, the patent applications listed often claim methods of disease detection that are not limited to specific probes or genes. This is a key strategy for obtaining commercially significant patent protection. Third, and most importantly, these patent applications overlie one of the primary goals of the Human Genome Project: the advancement of testing and possible treatment for genetic diseases ${ }^{2}$.

One may argue about whether or not the patent system will further this goal. It is undeniable, however, that the issue of "who owns the human genome" has been a subject of controversy since the early days of the genome project, when copyrights for genetic maps and sequences were being claimed ${ }^{3}$. Venter's patent application has served merely to reignite the controversy.

In addition to the listed patent applications, patent applications relating to genes associated with various cancers, atherosclerosis, familial hypercholesterolaemia and Alzheimer's disease have also been published. Even though Venoften. ment. ter is himself reported to have said that researchers would naturally want to take time to characterize sequences before publishing them ${ }^{4}$, the National Institutes of Health attorney in Venter's case, aware of this patent activity, must respond to the pressure to file early and

As more DNA is sequenced, more markers are discovered and more mapping is completed, it will become more urgent that the scientific (and business) community come to a clear understanding of what will - and will not - be in the public domain as a result of the Human Genome Project.

1689 Sunnyslope Drive,

Belmont, California 94002, USA

SIR - A group of research workers wishes to patent a ragbag assortment of anonymous human gene sequences derived from a cDNA library of brain tissue (Nature 353, 485 \& 785; 1991). I find this ludicrous, and suggestive of a lack of ethical and professional judge-

Was specific informed consent given by the owner (or former user) of the brain tissue used to construct the cDNA library? Did that person agree that the researchers could profit from his or her death, or was the donation given for the advancement of science and medicine rather than a few bank balances?

In fact, can the researchers really claim to have invented these sequences? Is not the real inventor the individual from whom they are derived, or his/her parents, grandparents and on back down the lineages to Olduvai and Lucy? Maybe we should credit natural selection, genetic mutation and random drift

\section{PATENTS RELATED TO GENETIC DISORDER}

\begin{tabular}{lll}
\hline $\begin{array}{l}\text { Serial number } \\
\text { EP 226 288 }\end{array}$ & $\begin{array}{l}\text { Institution } \\
\text { Collaborative Research } \\
\text { Corporation }\end{array}$ & $\begin{array}{l}\text { Subject matter } \\
\text { Testing for CF allele }\end{array}$ \\
EP 288 299 & $\begin{array}{l}\text { St Mary's Hospital Medical } \\
\text { School, UK School, UK }\end{array}$ & Diagnosis of CF with specified genomic DNA
\end{tabular}

EP $446017 \quad$ Genzyme Corporation

WO 91/10734 HSC Research Development Coproration, Toronto

Wo $90 / 15880$

USA

Wo $88 / 03572$

John Radcliffe Hospital, UK

wo $88 / 00979$

Children's Medical Centre, Boston, MA

U.S. $4,666,828$

Genera! Hospital Corporation, Boston MA

Wo 91/05044
DNA sequence comprising $\mathrm{CF}$ tranmembrane conductance regulator

CF DNA with specific mutation

Cell line transfected with CF gene

DNA sequence deleted in DMD

Detection of DMD using specified polymorphism

Test for HD. based on polymorphism

Yeast artificial chromosome containing mutant HD gene with the invention. Or, following the arguments of Richard Dawkins in The Extended Phenotype (Oxford University Press, 1983), we could regard the true inventor of the sequences to be the sequences themselves, with the individual being the organismal carrier they invented to propagate themselves.

On the matter of prior publication, the patent claim relies on the hope that these sequences have been published previously - in hundreds or thousands of copies in thousands or millions of brain cells in millions or billions of individuals for a fair chunk of evolutionary history. If they were not so expressed they would be of no interest, commercially or medically. I believe that these basic sequence data are a heritage we all share, and should share. Just because the book of life has not been written in human language does not give us the right to plagiarize (and patent) its contents.

\section{Wellcome Research Centre \\ for Parasitic Infections,}

Imperial College,

London SW7 2BB, UK

\section{Anderson, C. Nature 353, 485-486 (1991). \\ 2. Watson. J. Science 248, 44-49 (1990). \\ 3. Roberts, L. Science 237, 368-361 (1987) \\ 4. Roberts, L. Science 248, 953 (1990).}

\section{Page charges}

SIR - Publication charges are imposed on authors by some journals for (1) processing the manuscript for reviewing, (2) publication cost of each page and (3) the cost of reprints. Why do only some journals do this? Some authors do not have grants and even those who have grants may be reluctant to submit their papers to such journals because of strict regulations on foreign exchange; procuring even small amounts of foreign currency may be time-consuming, and no scientist would want to delay publication of his data.

Could not such journals waive page charges, at least for authors based in countries where there are strict foreign exchange regulations? Alternatively, could they not accept payment of the charges in any currency? They should at least remove the processing charges, which would provide an equal opportunity for all contributions, irrespective of the country of origin, to have their work critically reviewed by their peers.

Y. D. SHARMA

Department of Biotechnology,

All India Institute of Medical Sciences, New Delhi-110029, India

Letters submitted for Correspondence should be typed, doublespaced, on one side of the paper only. 